University of Nebraska - Lincoln

DigitalCommons@University of Nebraska - Lincoln

Geochemical evaluation of high sulfate levels in Ponca Creek, northeastern Nebraska

Jon C. Atkinson

Air Force Center for Engineering and the Environment, jon.atkinson@us.af.mil

Follow this and additional works at: https://digitalcommons.unl.edu/usafresearch

Part of the Aerospace Engineering Commons

Atkinson, Jon C., "Geochemical evaluation of high sulfate levels in Ponca Creek, northeastern Nebraska" (2012). U.S. Air Force Research. 36.

https://digitalcommons.unl.edu/usafresearch/36

This Article is brought to you for free and open access by the U.S. Department of Defense at DigitalCommons@University of Nebraska - Lincoln. It has been accepted for inclusion in U.S. Air Force Research by an authorized administrator of DigitalCommons@University of Nebraska - Lincoln. 


\section{Geochemical evaluation of high sulfate levels in Ponca Creek, northeastern Nebraska}

\author{
Jon C. Atkinson
}

\begin{abstract}
Most surface water and shallow groundwater occurring in northeastern Nebraska are of the calcium bicarbonate type, with minor concentrations (e.g., 10-200 mg/L) of sulfate $\left(\mathrm{SO}_{4}\right)$. Examination of historical water quality data (major cations and anions) for Ponca Creek, a predominantly ephemeral stream in northeastern Nebraska, revealed that $\mathrm{SO}_{4}$ concentrations ranged from about 110 to almost $1000 \mathrm{mg} / \mathrm{L}$ and contribute to a calcium sulfate hydrochemical facies. Consequently, most $\mathrm{SO}_{4}$ concentrations were above the U.S. Environmental Protection Agency secondary maximum contaminant level in drinking water of $250 \mathrm{mg} / \mathrm{L}$. Sulfate concentrations for the same period for a nearby stream, Verdigre Creek, range from about 20 to $120 \mathrm{mg} / \mathrm{L}$. Research into probable sources of the elevated $\mathrm{SO}_{4}$ in Ponca Creek revealed that a Late Cretaceous shale, the Pierre Shale, occurs at or near the land surface throughout most of the creek's drainage area, whereas alluvium, other Quaternary deposits, or the Tertiary Ogallala Formation comprises the streambed in Verdigre Creek. The Pierre Shale, encompassing soils formed on this Cretaceous shale, is rich in sulfate-bearing minerals (e.g., gypsum, pyrite, jarosite) that comprise the principal source of the high sulfate in drainage basin soils, alluvium, creek discharge, and shallow groundwater of the Ponca Creek watershed. A public domain geochemical speciation software (Visual MINTEQ) was used to investigate aqueous $\mathrm{SO}_{4}$ geochemistry of Ponca Creek flow. Calculated saturation indices for Ponca Creek waters suggest that they are slightly undersaturated with respect to gypsum and anhydrite despite significant sulfate dissolution and are slightly supersaturated with respect to calcite in numerous samples.
\end{abstract}

\section{INTRODUCTION}

From the late 1960s through about 1975, the Nebraska Department of Environmental Quality (NDEQ) and its predecessors (Nebraska

This article is a U.S. government work, and is not subject to copyright in the United States.

Copyright (C2012. The American Association of Petroleum Geologists/Division of Environmental Geosciences. All rights reserved.

DOI:10.1306/eg.12141111012

\section{AUTHOR}

Jon C. ATKInson Air Force Center for Engineering and the Environment (AFCEE)/restoration branch (TDV), 2261 Hughes Avenue, Suite 155, Lackland Air Force Base, Texas; jon.atkinson@us.af.mil

Jon C. Atkinson received an M.S. degree in geology, with emphasis on hydrogeology, in 1973 from the University of Nebraska. Mr. Atkinson has worked for the Air Force as an environmental hydrogeologist since November 1988. Previously, he worked for the Nebraska Department of Environmental Quality as a hydrogeologist for $15 \mathrm{yr}$. He has solely authored two groundwater/surface water quality articles in peer-reviewed journals.

\section{ACKNOWLEDGEMENTS}

This article is dedicated to the memory of Vincent H. Dreeszen (1921-2006), director of the Conservation and Survey Division (State Geological Survey), University of Nebraska-Lincoln, 1967 to 1987, who, as my M.S. thesis adviser 30 yr ago, nurtured my interest in groundwater quality and aqueous geochemistry. In addition, I greatly appreciate the detailed and constructive comments of the reviewers and editors that together have culminated in a notably improved article. 


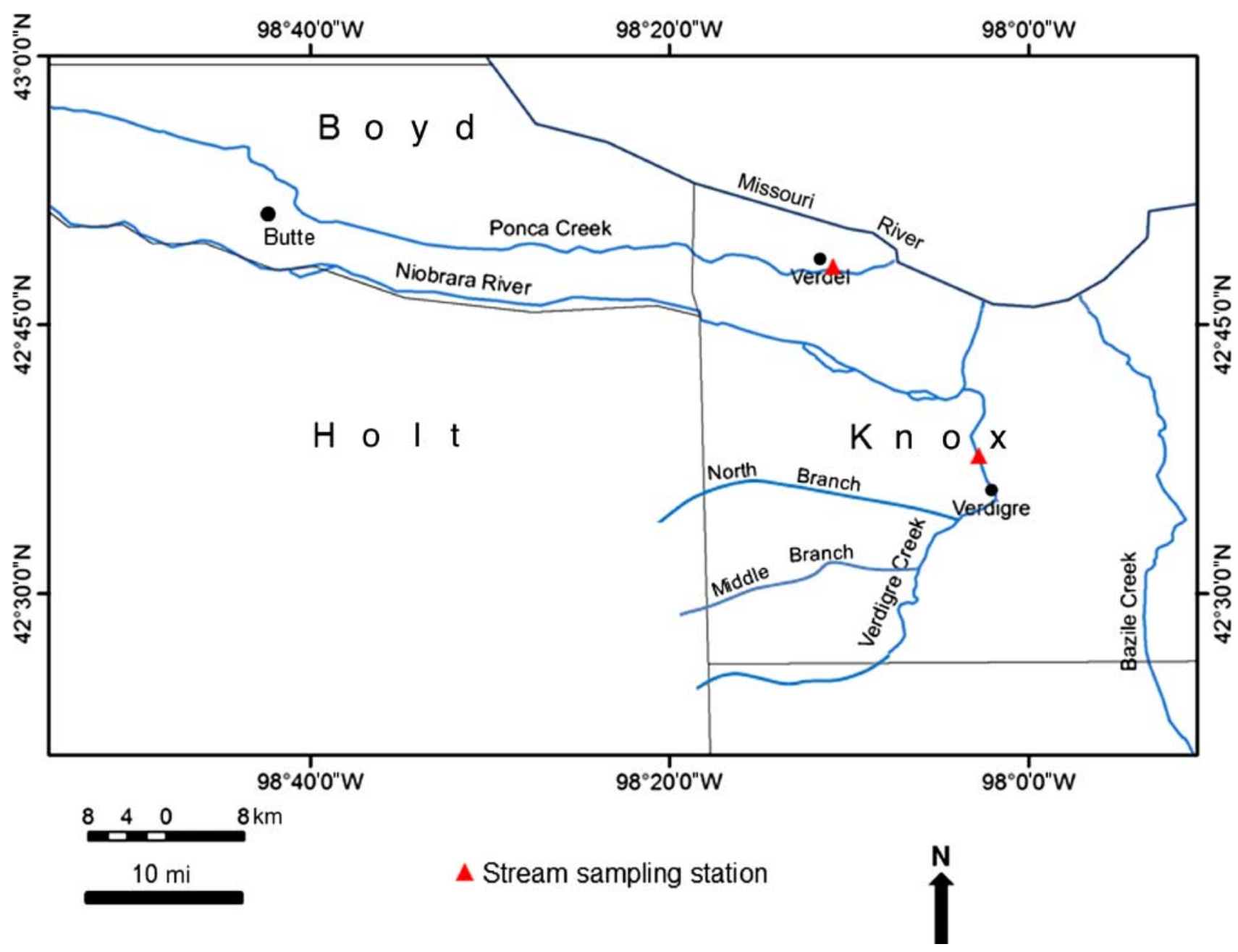

Figure 1. Ponca Creek and Verdigre Creek watersheds, northeastern Nebraska. Stream sampling stations are depicted with red triangles.

Department of Environmental Control and Department of Health) sampled numerous rivers and streams throughout the state, typically monthly, and analyzed the grab samples for all major ions, total dissolved solids (TDS), pH, and electrical conductance (EC). Subsequently, samples collected for the NDEQ surface water quality assessment program typically have not been analyzed for all major ions. Major ion analyses allow aqueous geochemical evaluation, encompassing hydrochemical facies determination and identification of probable parent material source(s). This study collects and evaluates available major ion data for two streams in northeast Nebraska, encompassing Ponca Creek, which discharges to the Missouri River, and Verdigre Creek, which flows into the Niobrara River (Figure 1). The NDEQ and U.S. Geological Survey (USGS) sampling location on Ponca Creek is approximately $1 \mathrm{~km}$ $(\sim 0.6 \mathrm{mi})$ east of Verdel $\left(42^{\circ} 48^{\prime} 40^{\prime \prime} \mathrm{N} ; 98^{\circ} 10^{\prime} 33^{\prime \prime} \mathrm{W}\right)$
(Figure 1). The NDEQ/USGS sampling station for Verdigre Creek is about $5.6 \mathrm{~km}(\sim 3.5 \mathrm{mi})$ north (downstream) of Verdigre $\left(42^{\circ} 39^{\prime} 16^{\prime \prime} \mathrm{N} ; 98^{\circ} 02^{\prime} 36^{\prime \prime} \mathrm{W}\right)$.

Also compiled and evaluated were major ion and other water quality parameters provided by the USGS during the period 1975 through 1980. Ponca Creek discharge is noteworthy because sulfate concentrations and TDS levels for the study period, 1969 through 1980, are significantly higher than those recorded for nearby streams, including Verdigre Creek. This creek, which lies about 15 to $40 \mathrm{~km}(\sim 9.3-25 \mathrm{mi})$ southeast of Ponca Creek, drains a part of western Knox County and the eastern part of Holt County.

The extensive major ion data for these two streams were initially evaluated for accuracy, modified where appropriate, and then analyzed using Visual MINTEQ (Gustafsson, 2009). This article documents the significant occurrence of sulfate in valley slope and bottomland 
soils, shallow bedrock, and shallow groundwater as the primary sources of the notably high and seemingly anomalous sulfate levels in Ponca Creek discharge.

The underlying hypotheses of this study are (1) that sulfate in the Ponca Creek watershed throughout Boyd and western Knox counties is predominantly a naturally occurring chemical and (2) sulfate sources and concentrations in soil and Ponca Creek discharge probably do not change appreciably with time. No sulfate analyses for Ponca Creek at Verdel since 1980 are known to exist; consequently, the second hypothesis cannot be tested.

\section{METHODS}

Major ion and related water quality analyses were obtained primarily from the STORET (STOrage and RETrieval) Data Warehouse (USEPA, 2011). These data resulted from the NDEQ sampling and analysis efforts for the approximate period 1969 through 1975. Additional major ion data for Ponca Creek at Verdel, Nebraska, for the period 1975 to 1980 were downloaded from the USGS Internet site (USGS, 2011).

To evaluate and enhance major ion data quality, concentrations expressed in milliequivalents per liter (meq/L) for the major ions, cation-anion balance errors, and numerous quality assurance ratios (e.g., calculated TDS/measured TDS, [0.01] $]^{*}[\mathrm{EC}$, in $\mu \mathrm{S} / \mathrm{cm}] / \mathrm{sum}$ of anions in meq/L, [0.01]*[EC]/sum of cations in meq/L) were used. For analyses that exceeded about 5\% cationanion balance errors, ion concentrations were revised using computer-based algorithms and revisions were constrained by the measured TDS concentrations, EC values, and several empirical water quality ratios, as described above.

Visual MINTEQ (Gustafsson, 2009), a Microsoft Windows version of the DOS-based computer code MINTEQA2 prepared for the U.S. Environmental Protection Agency (USEPA) (Allison et al., 1991), was used to calculate aqueous mineral saturation indices and $\mathrm{pCO}_{2}$ values. Visual MINTEQ contains an extensive and updated thermodynamic database. Eighty-three chemical analyses for Ponca Creek at Verdel were input to this equilibrium speciation model. For Verdigre Creek near Verdigre, 17 chemical analyses were input to Visual MINTEQ.

Pertinent data on soils in Boyd and western Knox counties (e.g., parent material, association/series classification, areal extent, soluble salt analyses) were obtained from written documentation (e.g., maps, reports, Webbased database [Web Soil Survey]) prepared by the Natural Resources Conservation Service (NRCS) of the U.S. Department of Agriculture (NRCS, 2011a).

\section{CLIMATE}

The climate of Boyd County and western Knox County is characterized by low humidity, cold winters, hot summers, and large variations in precipitation from month to month and from year to year. Mean daily temperatures range from about -1.1 to approximately $43^{\circ} \mathrm{C}$. The average annual precipitation at Butte, near the center of Boyd County, is slightly more than $56 \mathrm{~cm}$ (>22 in.) for the period 1907 through 1970. For the period 1958 to 1970 , the 3 months recording the highest monthly totals of precipitation were May, June (highest), and July (Souders, 1976).

\section{GEOGRAPHY AND GEOLOGY}

The land surface in Boyd County ranges in altitude from slightly less than $375 \mathrm{~m}(<1230 \mathrm{ft})$ above mean sea level at the eastern county boundary with Knox County to slightly more than $670 \mathrm{~m} \mathrm{(>2200} \mathrm{ft)} \mathrm{on} \mathrm{the} \mathrm{high} \mathrm{plain} \mathrm{in}$ the extreme northwestern corner of the county (Souders, 1976). Ponca Creek, whose headwaters are in South Dakota, flows easterly and southeasterly across Boyd County (Figure 1) and subsequently drains about 62\% of the county before discharging into the Missouri River in northwestern Knox County (Indra, 1979).

Comparison of the present land surface of Boyd County with that of the formerly extensive high plain, based on geomorphic remnants, suggests that more than 4.16 billion $\mathrm{m}^{3}\left(1.47 \mathrm{E}+11 \mathrm{ft}^{3}\right)$ of sediment have been eroded from the county since deposition of the sand and gravel beds capping the High Plains (Souders, 1976). Stream valleys in Boyd County are narrow compared with valleys of most other Nebraska streams (Souders, 1976).

Rocks representing the four major geologic eras, Precambrian, Paleozoic, Mesozoic, and Cenozoic, are present beneath Boyd County and western Knox County. Precambrian and Paleozoic rocks occur at great depth, and no water supply wells were known to be screened in these stratigraphic units circa 1975 (Souders, 1976). Rocks of the Dakota Group, a sequence of stratigraphic units deposited during the Late Cretaceous, underlie all of Boyd County and western Knox County. Depth to 
Figure 2. Bedrock geology of the study area. Modified from Engberg (1984). Depicted bedrock units are the uppermost bedrock formations, typically mantled by varying thicknesses $(0-30 \mathrm{~m}[0-98 \mathrm{ft}])$ of Quaternary deposits.

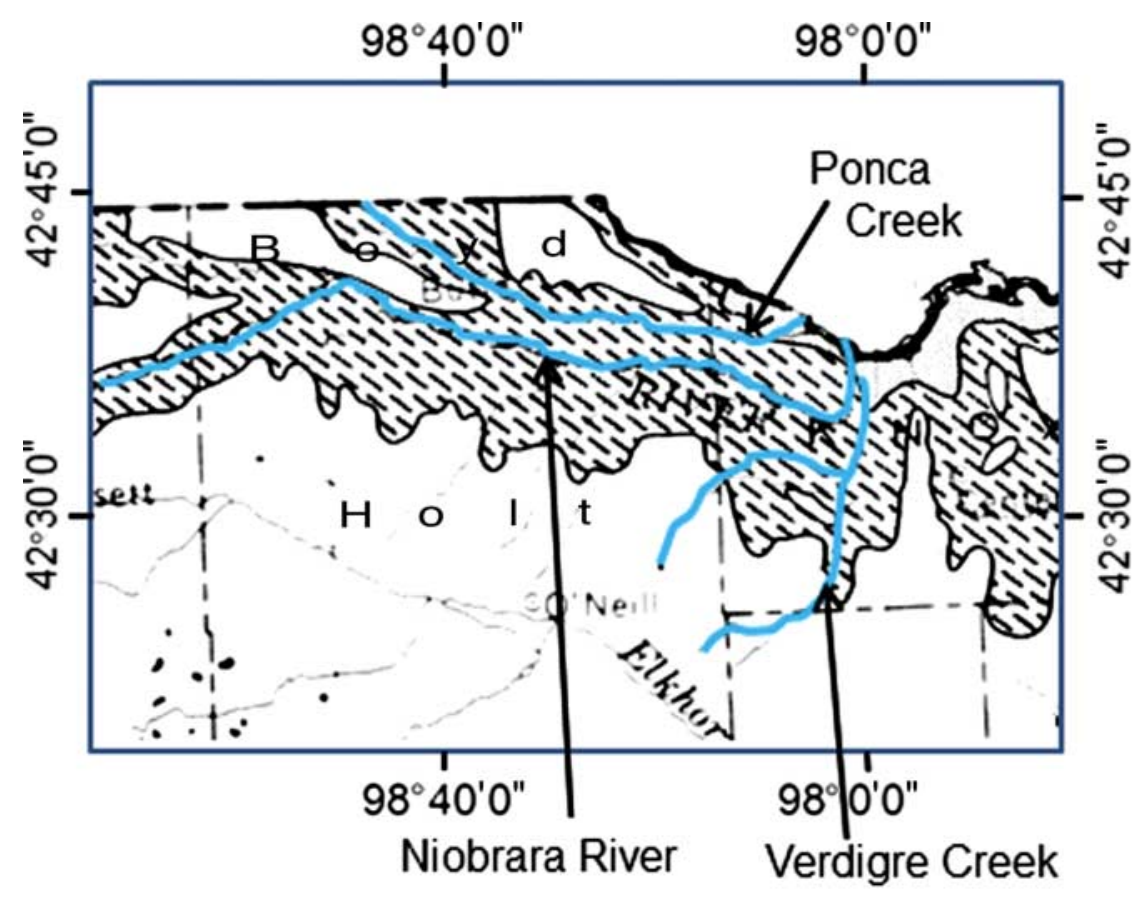

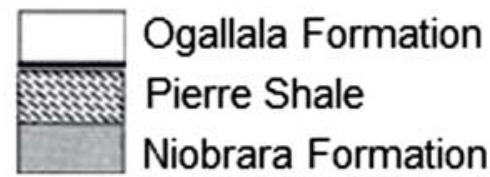

\section{$40 \mathrm{~km}$}

\section{$25 \mathrm{mi}$}

the top of the Dakota Group in Boyd County is approximately $180 \mathrm{~m}(\sim 590 \mathrm{ft})$ in the Missouri River and Ponca Creek valleys in the eastern part of the county and increases westward to about $430 \mathrm{~m}(\sim 1400 \mathrm{ft})$ beneath the high plain in the northwestern part and southwestern corner of Boyd County (Souders, 1976). The Niobrara Formation lies above the Dakota Group and outcrops at the base of the escarpment, traversing the southern side of the Missouri River valley (Figure 2).

The Niobrara Formation is overlain by the nearly impervious Pierre Shale, the uppermost Cretaceous and Mesozoic stratigraphic unit in Boyd County and western Knox County. The Pierre Shale crops out or is only thinly mantled by sediments of the Tertiary and the Quaternary or of solely the Quaternary throughout large areas in Boyd and western Knox counties (Figure 2) principally caused by the significant fluvial erosion described above. The Pierre Shale is subdivided into three members in ascending order: (1) an unnamed member; (2) the Mobridge Member; and (3) the Elk Butte Member.
The unnamed member principally consists of bentonitic clay shale. The overlying Mobridge Member is composed of beds of shaly chalk and calcareous shale that range in aggregate thickness from 49 to $61 \mathrm{~m} \mathrm{(160-}$ $200 \mathrm{ft}$ ). It is exposed along the steep valley sides of Ponca Creek in the eastern and central parts of Boyd County. Excessive amounts of sulfate and selenium in groundwater from shallow wells in eastern Boyd County are probably caused by the contact of groundwater with the Mobridge Member or sediments derived from weathering of the Mobridge (Souders, 1976).

In many places on the uplands bordering Ponca Creek, Tertiary (Miocene[?], hereafter Miocene) sediments, primarily silt beds, immediately overlie the Pierre Shale (Souders, 1976). The Ogallala Formation or Group of Pliocene age was deposited on the Miocene silt beds or Pierre Shale (where Miocene silts were completely removed by erosion) in parts of the uplands (Figure 2). Fine sand, some silty or clayey, and fine-grained sandstone are the predominant lithologies of the Ogallala 


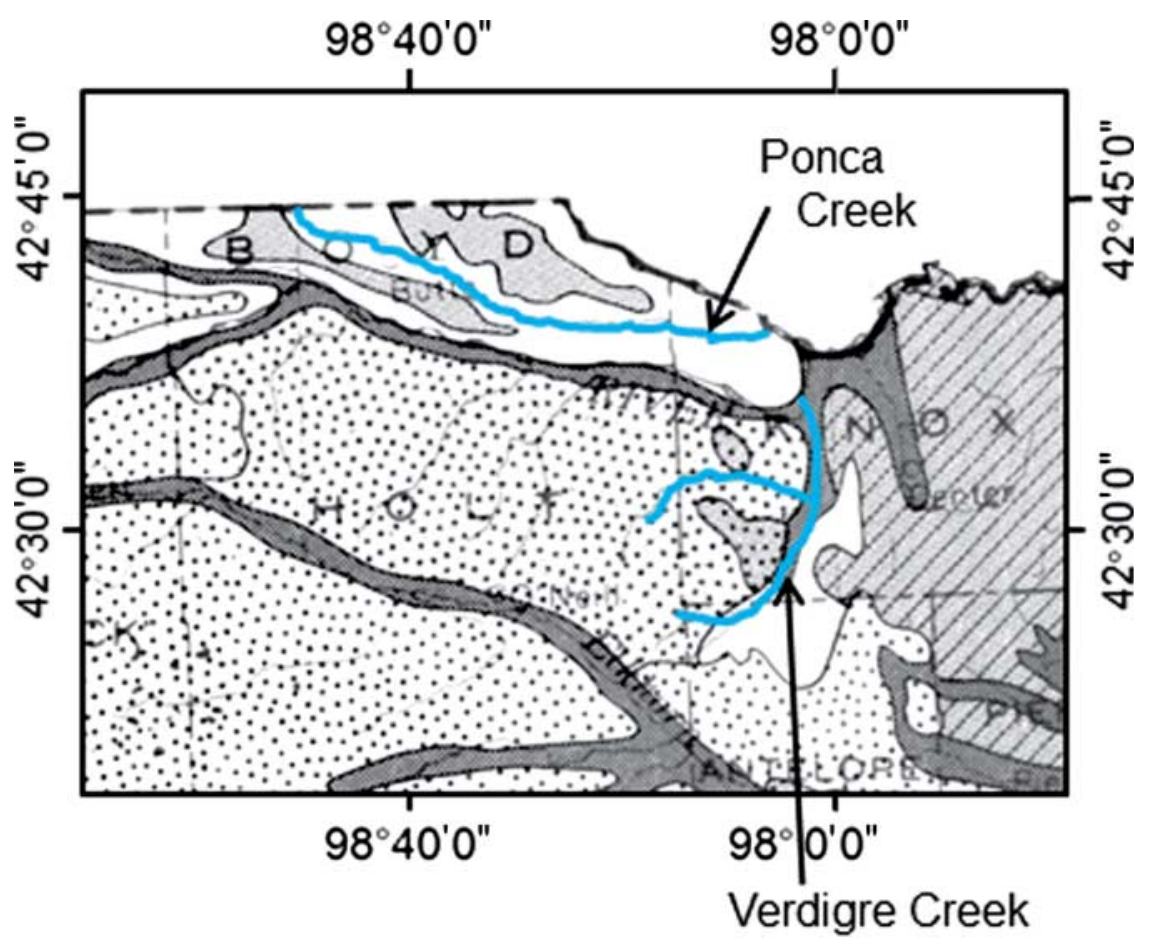

Figure 3. Areal distribution of Holocene and Pleistocene deposits in the study area. Modified from Engberg (1984).

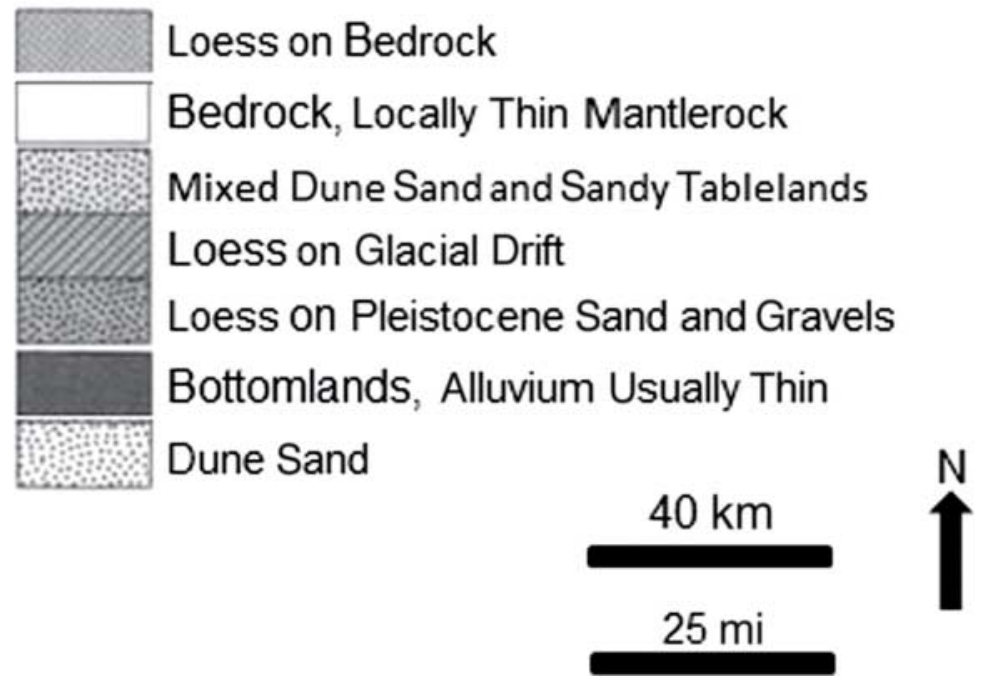

Formation (Souders, 1976). Tertiary sediments (Miocene silt and/or Ogallala Formation) north of Ponca Creek in upland areas pinch out about $6 \mathrm{~km}(\sim 3.7 \mathrm{mi})$ west of Knox County. South of Ponca Creek, Tertiary strata extend eastward from the extreme western part of Boyd County to a position approximately $30 \mathrm{~km}$ $(\sim 19 \mathrm{mi})$ west of Knox County because of significant post-Pliocene erosion.

Unconsolidated deposits of Quaternary age occur in widely different topographic positions throughout Boyd and western Knox counties. Much of the upland in Boyd County is mantled by wind-deposited fine sand and silt (predominantly loess) of Quaternary age. These deposits also occupy high terraces along Ponca Creek. Sediments deposited by streams and wind in Boyd County range in texture from coarse to fine (Souders, 1976). Where penetrated by test drilling, Quaternary deposits range in thickness from 3 to more than $30 \mathrm{~m}$ (10 to $>98 \mathrm{ft}$ ). As illustrated on Figure 3, the steep-sided Ponca Creek valley throughout its course in Boyd and Knox counties is devoid of Pleistocene/Holocene deposits or, at most, only thinly mantled by these deposits. In contrast, in the Verdigre Creek watershed, the Pierre Shale is overlain throughout most of its areal extent by Quaternary alluvium, mixed dune sand and sandy tablelands, loess, or Ogallala Formation deposits (Figure 3). 


\section{SURFACE WATER HYDROLOGY}

Ponca Creek and its tributaries drain about $62 \%$ of Boyd County. The Pierre Shale is exposed (or is the surficial bedrock) in the drainage basin area, contributing most of the runoff reaching Ponca Creek. The shale is too fine textured and compacted to absorb moisture readily. Precipitation falling on these areas runs off rapidly because slopes are steep and the shale has little capacity for water infiltration (Souders, 1976).

Springs and seeps occur in many places in the Ponca Creek valley along the base of the high terrace deposits (principally Quaternary in age) (Souders, 1976). Springs and seeps are common at the contact of the water table and the steeply sloping breaks of Ponca Creek in the central part of the county (Rahn and Davis, 1989; Byrd and Kaplan, 1994; Davis and Long, 1998).

The flow of Ponca Creek, whose drainage area consists mostly of exposed Pierre Shale, is derived almost wholly from overland runoff and only negligibly from groundwater seepage. Consequently, the discharge along this stream is highly variable, as documented by relatively extensive discharge data. For the period of record, October 1959 through September 1970, the minimum daily, median annual, and maximum instantaneous discharges were 0,1470 , and 445,000 L/s (0, 388, and 118,000 gal/s), respectively (Souders, 1976). For this study, measurable discharges $(n=72)$ at the Verdel gaging station in the USEPA's STORET database for the period May 1968 through December 2006 ranged from $0.57 \mathrm{~L} / \mathrm{s}(0.15 \mathrm{gal} / \mathrm{s})$ (November 1968 and September 1971$)$ to $25,000 \mathrm{~L} / \mathrm{s}\left(25 \mathrm{~m}^{3} / \mathrm{s} ; 6600 \mathrm{gal} / \mathrm{s}\right.$ ) (April 1969), with a daily median flow of $370 \mathrm{~L} / \mathrm{s}\left(0.37 \mathrm{~m}^{3} / \mathrm{s}\right.$; $98 \mathrm{gal} / \mathrm{s}$ ).

For Verdigre Creek near Verdigre, measured discharges for the period 1975 to 2006 ranged from 595 to $19,700 \mathrm{~L} / \mathrm{s}(157-5200 \mathrm{gal} / \mathrm{s})$, with a median value of $3170 \mathrm{~L} / \mathrm{s}(3.17 \mathrm{~m}$ /s; $837 \mathrm{gal} / \mathrm{s})$. Measured discharge is higher and less variable compared with that of Ponca Creek, suggesting that Verdigre Creek most likely is a perennial (groundwater-fed) stream throughout most of its course. This hypothesis is consistent with the hydrogeology of the drainage basin as described below.

\section{HYDROGEOLOGY AND HYDROCHEMISTRY}

Aquifers situated at shallow to moderate depth below the study area encompass the Dakota Group, Tertiary deposits, principally the Ogallala Formation, and satu- rated Quaternary sediments. Taken together, the Ogallala Formation and Quaternary sediments comprise the High Plains Aquifer (sedimentary formations ranging in age from 33 m.y. to present). The dominant deposits in the High Plains Aquifer are river- and wind-deposited sands (Diffendal, 2004).

In the upland areas where Miocene silt beds, the Ogallala Aquifer, and/or Quaternary stratigraphic units are water bearing, the water table slopes toward valleys, encompassing Ponca Creek, that are incised into the Pierre Shale. In valley alluvium, the water table is highest along the valley edges and slopes in the downstream direction. Groundwater discharging along steep valley slopes is either taken up by bottomland vegetation or seeps into the stream channel (Souders, 1976). Ponca Creek is a perennial stream in the vicinity of Butte; discharge is maintained mostly by groundwater notably from Tertiary strata (Rahn and Davis, 1989; Davis and Long, 1998).

Researchers have identified a close correlation between precipitation and fluctuations of the water table in Boyd County; the water table rises in immediate response to precipitation (U.S. Ecology, 1990; Davis and Long, 1998). The water table also fluctuates seasonally (Souders, 1976). In addition, U.S. Ecology (1990) noted a water table response to periods of above-normal precipitation, as shown by measured water levels during 1993 and 1994.

Groundwater from the Miocene silt beds, the Ogallala Formation, and the Quaternary deposits in the uplands is moderately hard to hard but generally is of acceptable quality for most uses. Water in the low terrace deposits and alluvium in the Ponca Creek valley is characterized by excessive hardness and in some locations by very high concentrations of sulfate (Souders, 1976).

Compared with other aquifers in Boyd County, water in the valley alluvium has the greatest range in concentration of TDS. In addition, this groundwater typically is harder and has higher concentrations of iron, manganese, and sulfate than water from most wells that tap either the Cenozoic rocks underlying the high and intermediate plains or the high terrace deposits. Groundwater from sampled wells in Ponca Creek valley east of about $98^{\circ} 35^{\prime} 40^{\prime \prime}$ longitude is extremely high in sulfate, has large concentrations of dissolved solids, and is notably hard. The probable source of the sulfate and hardness is the Pierre Shale, which immediately underlies the valley and provides sediment to the valley alluvium (Souders, 1976). Engberg (1984) noted that concentrations of $\mathrm{SO}_{4}$ ranging between 1000 and $2000 \mathrm{mg} / \mathrm{L}$ have been detected in groundwater from 
Table 1. Soluble Salt Analyses for $\mathrm{SO}_{4}, \mathrm{Ca}$, and $\mathrm{HCO}_{3}$ for Five Soil Series, Boyd County, Nebraska

\begin{tabular}{|c|c|c|c|}
\hline \multirow[b]{2}{*}{ Soil Series (Texture) } & \multirow[b]{2}{*}{ Location } & \multicolumn{2}{|c|}{ Soluble Salt Analysis } \\
\hline & & Horizon (Depth $[\mathrm{cm}]$ ) & Ion Concentration (mmol/L) \\
\hline Labu (silty clay to shaly clay) & $\begin{array}{c}42^{\circ} 59^{\prime} 13^{\prime \prime} 98^{\circ} 57^{\prime} 15^{\prime \prime} \\
(\sim 1.5 \mathrm{~km} \mathrm{~N} \text { of Ponca Creek) }\end{array}$ & $A(0-15)$ & $\mathrm{SO}_{4}$, trace; $\mathrm{Ca}, 6.1 ; \mathrm{HCO}_{3}, 6.3$ \\
\hline Sansarc (shaly clay) & $\begin{array}{c}42^{\circ} 47^{\prime} 17^{\prime \prime} 98^{\circ} 23^{\prime} 32^{\prime \prime} \\
(\sim 4 \mathrm{~km} \mathrm{~S} \text { of Ponca Creek) }\end{array}$ & $A(0-15)$ & $\mathrm{SO}_{4}, 0.1 ; \mathrm{Ca}, 5.0 ; \mathrm{HCO}_{3}, 6.1$ \\
\hline Bristow (shaly clay) & $\begin{array}{c}42^{\circ} 49^{\prime} 36^{\prime \prime} 98^{\circ} 35^{\prime} 06^{\prime \prime} \\
(\sim 1.5 \mathrm{~km} \text { S of Ponca Creek) }\end{array}$ & $\begin{array}{l}\text { A }(0-18) \\
\text { C }(18-43) \\
\text { Cr2 }(64-79) \\
\text { Cr3 (79-99) } \\
\text { Cr4 (99-152) }\end{array}$ & $\begin{array}{l}\mathrm{SO}_{4}, 20.6 ; \mathrm{Ca}, 22.7 \\
\mathrm{SO}_{4}, 32.8 ; \mathrm{Ca}, 35.6 \\
\mathrm{SO}_{4}, 32.7 ; \mathrm{Ca}, 33.8 \\
\mathrm{SO}_{4}, 33.7 ; \mathrm{Ca}, 32.6 \\
\mathrm{SO}_{4}, 32.6 ; \mathrm{Ca}, 32.9\end{array}$ \\
\hline Lynch (silty clay) & $\begin{array}{c}42^{\circ} 50^{\prime} 04^{\prime \prime} 98^{\circ} 35^{\prime} 02^{\prime \prime} \\
(\sim 0.5 \mathrm{~km} \text { S of Ponca Creek })\end{array}$ & $\begin{array}{l}\text { Ap }(0-10) \\
\mathrm{Cr}(84-152)\end{array}$ & $\begin{array}{l}\mathrm{SO}_{4}, 4.2 ; \mathrm{Ca}, 10.6 \\
\mathrm{SO}_{4}, 31.7 ; \mathrm{Ca}, 32.5\end{array}$ \\
\hline Reliance (silty clay loam) & $\begin{array}{l}\quad 42^{\circ} 54^{\prime} 26^{\prime \prime} 98^{\circ} 46^{\prime} 21^{\prime \prime} \\
(\sim 150 \mathrm{~m} \text { from tributary } \mathrm{S} \\
\text { of Ponca Creek) }\end{array}$ & $\begin{array}{l}\text { Ap }(0-15) \\
A(15-30)\end{array}$ & $\begin{array}{l}\mathrm{SO}_{4}, 1.2 ; \mathrm{Ca}, 1.6 \\
\mathrm{SO}_{4}, 2.9 ; \mathrm{Ca}, 2.5\end{array}$ \\
\hline & & $\begin{array}{l}\text { Bt1 }(30-46) \\
\text { Bt3 }(61-81) \\
\text { C (81-109) }\end{array}$ & $\begin{array}{l}\mathrm{SO}_{4}, 6.3 ; \mathrm{Ca}, 6.6 \\
\mathrm{SO}_{4}, 8.7 ; \mathrm{Ca}, 9.2 \\
\mathrm{SO}_{4}, 6.3 ; \mathrm{Ca}, 6.4\end{array}$ \\
\hline
\end{tabular}

several wells produced from the Holocene-Pleistocene aquifers in Boyd County. Because recharge to these wells is slow, the wells most likely have been drilled deeper than otherwise necessary into the underlying weathered Pierre Shale bedrock to provide storage reservoirs for these wells. This exposed weathered Pierre Shale is a direct source of sulfides that are readily oxidized to $\mathrm{SO}_{4}$.

\section{SULFUR IN THE PIERRE SHALE}

For a USGS study of the mineralogy of the Pierre Shale in the upper Midwest (Wyoming, Montana, North Dakota, South Dakota, and northern Nebraska), Schultz et al. (1980) determined the mean percentages of sulfur species to be $\mathrm{S}, 0.37 ; \mathrm{S}^{2-}, 0.25$; and $\mathrm{SO}_{3}, 0.38$. Pyrite, commonly in small amounts, was found only in marine rocks, most commonly in offshore marine facies. Gypsum, jarosite, and pyrite are distributed in similar proportions because these sulfate minerals are surficial weathering products of pyrite. All were found to be more common in the eastern study area (North Dakota, South Dakota, and Nebraska) than the western and northern parts (Wyoming and Montana). At the single sample location in Nebraska (Niobrara, Nebraska), gypsum ranged from 1 to $15 \%$ by weight and occurred in up to $25 \%$ of the samples. At Niobrara, jarosite ranged from 1 to $5 \%$ in up to $24 \%$ of samples, and pyrite averaged $5 \%$ by weight in $25 \%$ of all samples (Schultz et al., 1980). Sulfur is abundant in organic-rich marine shale both as $\mathrm{S}^{2-}$ in pyrite and $\mathrm{SO}_{3}$ in secondary gypsum or jarosite. In the Schultz et al. (1980) study, marine organic-rich fissile shale samples $(\mathrm{n}=7)$ contained $3.9 \% \mathrm{~S}, 2.6 \% \mathrm{~S}^{2-}$, and $3.2 \% \mathrm{SO}_{3}$. The notable association between total $\mathrm{S}$ and organic carbon results from reducing conditions created by accumulating organic matter. These reducing conditions are favorable for the direct reduction of $\mathrm{SO}_{4}$ in normal marine water to sulfide as well as for the proliferation of sulfate-reducing bacteria that are important intermediaries in the reduction process (Degens, 1965; Schultz et al., 1980).

Pyrite occurring in the Pierre Shale (Souders, 1976; Schultz et al., 1980) is exposed to oxidation as overland runoff across steep valley slopes of Ponca Creek erodes the Pierre. This ongoing exposure, weathering, and oxidation of pyrite produce $\mathrm{SO}_{4}$ in accordance with the following chemical reaction:

$$
\mathrm{FeS}_{2}(\mathrm{~s})+3.5 \mathrm{O}_{2}+\mathrm{H}_{2} \mathrm{O} \rightarrow \mathrm{Fe}^{+2}+2 \mathrm{SO}_{4}^{-2}+2 \mathrm{H}^{+}
$$

(Zipper, Skousen, and Jage, 2011). 
Figure 4. Piper trilinear diagram showing the percentages of cation and anion concentrations expressed in meq/L for Ponca and Verdigre creeks. The three data points depicted for each creek encompass two representative sample analyses and a hypothetical one composed of median concentrations.

\section{Explanation \\ - Ponca Creek \\ - Verdigre Creek}

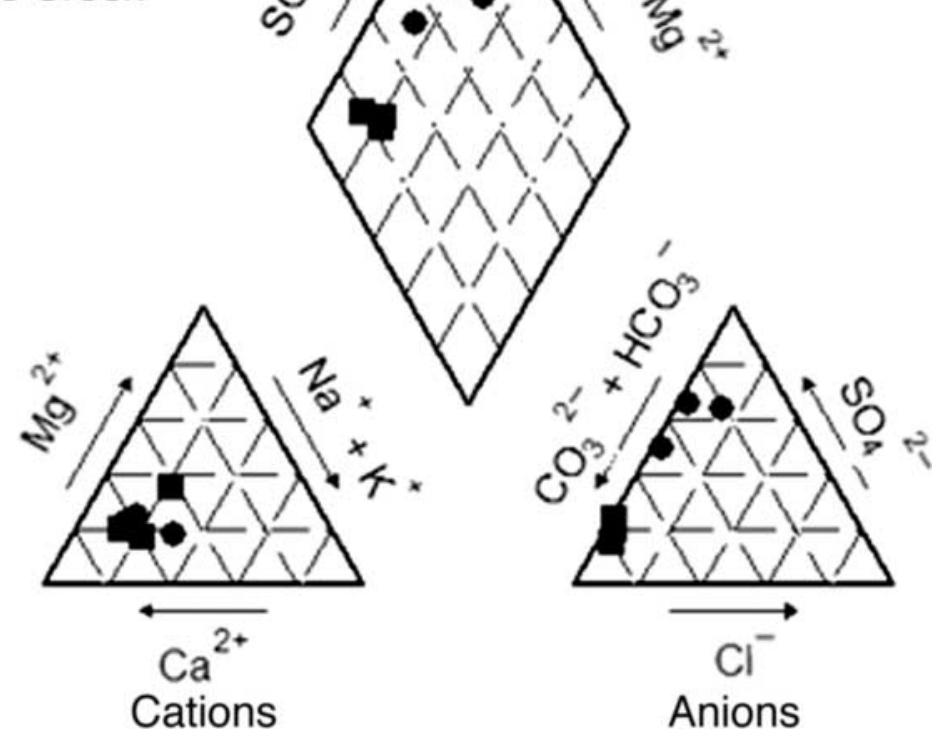

\section{SULFATE IN SOILS}

The organic sulfur fraction accounts for more than 95\% of the total S in most soils in humid and semihumid regions (Tabatabai, 1982). The proportion of organic and inorganic $\mathrm{S}$ in a soil sample varies widely according to soil properties ( $\mathrm{pH}$, moisture status, organic matter, clay content, and depth of sampling) (Tabatabai, 1996; Pierzynski et al., 2000). Mineralization of organic S and its conversion to sulfate by chemical and biological activity commonly provide a source of plant-available S. Total S typically ranges from 0.01 to $0.05 \%$ in most mineral soils but can be greater in organic soils. In welldrained soils, most of the inorganic S normally occurs as sulfate (NRCS, 2011b).

In general, the anion concentration in the aqueous phase of nonsaline soils is less than the cation concentration because of a net negative surface charge (Bohn et al.,
1979; Sposito, 1989); anions rapidly leach to the subsurface. The difference between the sums of cation and anion charges narrows as soil salinity increases because of the saturation of the exchange complex. The relative amounts of major anions $\left(\mathrm{NO}_{3}^{-}, \mathrm{SO}_{4}^{2-}, \mathrm{Cl}^{-}\right.$, and $\left.\mathrm{HCO}_{3}^{-}\right)$vary with fertilizer and management practices, mineralogy, microbial and higher plant activity, saltwater encroachment, irrigation water quality, and atmospheric fallout. In humid regions, the sum of anions rarely exceeds $0.01 \mathrm{M}(10 \mathrm{mmol})$ in soil solution (Bohn et al., 1979; NRCS, 2011b).

Numerous soil series and associations in Boyd and northwestern Knox counties have developed on the weathered Pierre Shale or on sediment derived from this shale. The Labu-Sansarc association is moderately deep and shallow, strongly sloping to very steep, welldrained clayey soils formed in residuum from shale. This upland soil makes up about $24 \%$ of the county.

Table 2. Summary Statistics for Chemical-Quality Parameters $(n=83)$, Ponca Creek at Verdel, Nebraska*

Calcite $\mathrm{SI}>0$

\begin{tabular}{|c|c|c|c|c|c|c|c|c|c|c|c|}
\hline Parameter & $\mathrm{Ca}$ & $\mathrm{Mg}$ & $\mathrm{Na}$ & K & $\mathrm{HCO}_{3}$ & $\mathrm{Cl}$ & $\mathrm{SO}_{4}$ & TDS & $\mathrm{EC}(\mu \mathrm{S} / \mathrm{cm})$ & Calc. $\mathrm{pCO}_{2}(\mathrm{~atm})$ & $(\log [\mathrm{IAP} / \mathrm{K}])^{* *}$ \\
\hline Range & $51-376$ & $9-98$ & $5-210$ & $9-30$ & $124-459$ & $2-162$ & 107-998 & $360-2220$ & $451-3250$ & $5.12 \mathrm{E}-4-2.47 \mathrm{E}-2$ & $0.083-1.28$ \\
\hline Median & 165 & 43 & 46 & 15 & 278 & 18 & 450 & 980 & 1240 & $2.51 \mathrm{E}-03$ & 0.693 \\
\hline Average & 169 & 44 & 50 & 15 & 274 & 23 & 450 & 992 & 1356 & $3.75 \mathrm{E}-03$ & 0.696 \\
\hline
\end{tabular}

*Concentrations in $\mathrm{mg} / \mathrm{L}$ except as noted. For calcite positive saturation index (SI) (supersaturation) values, $\mathrm{n}=74$.

**IAP = ion activity product; $\mathrm{K}=$ calcite solubility constant. 
Table 3. Summary Statistics for Chemical-Quality Parameters $(n=17)$, Verdigre Creek Near Verdigre, Nebraska*

Calcite $\mathrm{SI}>0$

\begin{tabular}{|c|c|c|c|c|c|c|c|c|c|c|c|}
\hline Parameter & $\mathrm{Ca}$ & $\mathrm{Mg}$ & $\mathrm{Na}$ & K & $\mathrm{HCO}_{3}$ & $\mathrm{Cl}$ & $\mathrm{SO}_{4}$ & TDS & $\mathrm{EC}(\mu \mathrm{S} / \mathrm{cm})$ & Calc. $\mathrm{pCO}_{2}(\mathrm{~atm})$ & $(\log [\mathrm{IAP} / \mathrm{K}])^{* *}$ \\
\hline Range & $20-58$ & $3-11$ & $2-19$ & $3-14$ & $107-224$ & $1-11$ & $11-49$ & $178-296$ & $210-410$ & 4.75E-04-2.69E-02 & $0.235-1.10$ \\
\hline Median & 50 & 9.0 & 10 & 5.0 & 185 & 6.0 & 27 & 230 & 315 & $1.26 \mathrm{E}-03$ & 0.60 \\
\hline Average & 46 & 8.4 & 12 & 6.6 & 178 & 5.4 & 27 & 232 & 310 & 4.18E-03 & 0.60 \\
\hline
\end{tabular}

*Concentrations in $\mathrm{mg} / \mathrm{L}$ except as noted. For calcite positive saturation index (SI) (supersaturation) values, $\mathrm{n}=13$.

**IAP = ion activity product; $\mathrm{K}=$ calcite solubility constant.

The Bristow-Lynch association is shallow and moderately deep, gently sloping to very steep, well-drained to excessively drained clayey soils formed in residuum from calcareous and gypsiferous chalky shale. This clayey upland association makes up 16\% of the county (Indra, 1979). The National Soil Science Laboratory (National Cooperative Soil Survey, National Cooperative Soil Characterization Database) maintains a Web-based database for soil analysis results (NRCS, 2011c). This NRCS database contains characterization data for single samples of Labu, Sansarc, Bristow, Lynch, and Reliance series. Available soluble salts data for these five soil series are summarized in Table 1. Maximum $\mathrm{SO}_{4}$ concentration is $33.7 \mathrm{mmol} / \mathrm{L}$; and maximum $\mathrm{Ca}$ concentration is $35.6 \mathrm{mmol} / \mathrm{L}$ (Bristow series). Note that for most soil horizons, the molar ratio of $\mathrm{SO}_{4}$ to $\mathrm{Ca}$ is approximately 1.0 , suggesting the presence of gypsum in these Pierre Shale-derived soils.

The Assistant State Soil Scientist, Nebraska, NRCS, U.S. Department of Agriculture, while in the Ponca Creek watershed after a recent rainfall, has reported

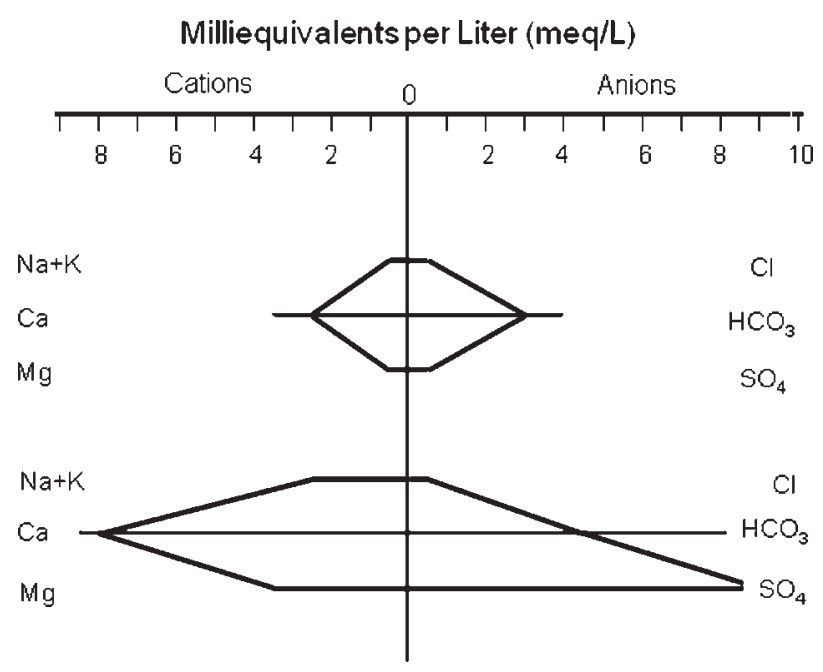

Figure 5. Stiff diagrams depicting median ion concentrations (meq/L) for Ponca (lower diagram) and Verdigre creeks. smelling sulfur in the air (D. Shurtliff, 2011, personal communication). One plausible explanation is that the sulfur-rich soil and bedrock release $\mathrm{H}_{2} \mathrm{~S}$ or other odorous sulfide(s) when storm runoff traverses Ponca Creek valley slopes.

\section{RESULTS AND DISCUSSION}

The hydrochemical facies of Ponca Creek discharge at Verdel from May 1969 through May 1980 is calcium sulfate. This geochemical classification is graphically depicted in Figure 4, a Piper trilinear diagram (Piper, 1944). Three representative sample analyses, including a hypothetical one composed of median concentrations, are depicted. Plotted values are percentages of total cation or anion concentrations expressed in $\mathrm{meq} / \mathrm{L}$. Sulfate concentrations for the representative sample analyses are 195, 450, and $895 \mathrm{mg} / \mathrm{L}$. For the study period, sulfate content ranged from 107 (February 1975) to $998 \mathrm{mg} / \mathrm{L}$ (January 1972), and the median $\mathrm{SO}_{4}$ value was $450 \mathrm{mg} / \mathrm{L}$. For the 83 samples evaluated, calcium concentrations ranged from 51 (October 1973) to $376 \mathrm{mg} / \mathrm{L}$ (January 1972), and the median value was $165 \mathrm{mg} / \mathrm{L}$. The TDS values ranged from 360 (February 1975) to $2220 \mathrm{mg} / \mathrm{L}$ (January 1972), with a median of $980 \mathrm{mg} / \mathrm{L}$.

The median ratio of $\mathrm{SO}_{4}$ to $\mathrm{Ca}$, as expressed in $\mathrm{meq} / \mathrm{L}$ is 1.1 , suggesting dissolution of gypsum as the principal source of high sulfate and calcium concentrations in Ponca Creek discharge. In contrast, the ratio of $\mathrm{SO}_{4}$ to $\mathrm{Ca}$, as expressed in meq/L, for Verdigre Creek is 0.24 . For the period investigated, Ponca Creek bicarbonate ranged from a low of $124 \mathrm{mg} / \mathrm{L}$ in November 1975 to $459 \mathrm{mg} / \mathrm{L}$ in January 1972, with a median of $278 \mathrm{mg} / \mathrm{L}$. Comparing the median values for $\mathrm{SO}_{4}$ and TDS reveals that sulfate accounts for almost one half of the TDS in Ponca Creek discharge. Ranges, medians, and averages for other major ions and selected geochemical parameters are enumerated in Table 2. 
By comparison, nearby Verdigre Creek produces water whose hydrochemical facies is calcium bicarbonate (Figure 4). The three representative sample analyses depicted have TDS levels ranging from 230 to $268 \mathrm{mg} / \mathrm{L}$. For the period August 1968 through October 1975, the sulfate, calcium, bicarbonate, and TDS levels were significantly lower than those recorded for Ponca Creek. Sulfate concentrations ranged from 11 to $49 \mathrm{mg} / \mathrm{L}$; calcium varied from 20 to $58 \mathrm{mg} / \mathrm{L}$; bicarbonate levels ranged from 107 to $224 \mathrm{mg} / \mathrm{L}$; and TDS values varied from 178 to $296 \mathrm{mg} / \mathrm{L}$. In addition, median and average values $(\mathrm{n}=17)$ for these four constituents and ranges, medians, and averages for other major ions and selected geochemical parameters are enumerated in Table 3.

A line of evidence that highly dissolved $\mathrm{SO}_{4}$ in Ponca Creek is not derived from groundwater irrigation during the investigative time frame is the comparison with sulfate concentrations reported for the Platte River in south-central Nebraska. Spalding and Exner (1980) collected 10 river samples between July 1975 and July 1976 from an area of intense agricultural development, encompassing heavy groundwater irrigation. Measured Platte River sulfate concentrations ranged from about 220 to $290 \mathrm{mg} / \mathrm{L}$, significantly lower than the median $\mathrm{SO}_{4}$ level of $450 \mathrm{mg} / \mathrm{L}$ for Ponca Creek. An unequal dilution effect, however, may partially account for this significant concentration difference. The density of irrigation wells is a related line of evidence that irrigated agriculture was not a principal source of high sulfate concentrations in Ponca Creek during the study period. A map in Engberg (1984) depicts low 1982 registered irrigation-well density throughout Boyd County, whereas irrigation-well density was high in the Platte River valley of south-central Nebraska.

Stiff diagrams (Stiff, 1951) depict major ion composition (as meq/L) and are useful in comparing the ionic composition (hydrochemical facies) and TDS of streams or aquifers of interest. Piper diagrams (i.e., Figure 4) are not useful for the latter purpose because they illustrate percentages of major anions and cations-not concentrations of these ions. The size of the polygon creating the Stiff diagram is an indication of the TDS concentration (Bartos and Ogle, 2002; Atkinson, 2011). Figure 5 depicts Stiff diagrams for hypothetical median ion concentration distribution for Ponca and Verdigre creeks. These diagrams clearly show the significantly higher $\mathrm{SO}_{4}$ and Ca concentrations, as well as TDS content, of Ponca Creek water compared with Verdigre Creek discharge.

As sulfate concentrations in water increase, an increasing proportion of the $\mathrm{SO}_{4}$ in solution becomes tied up in ion pairs (e.g., $\mathrm{NaSO}_{4}, \mathrm{CaSO}_{4}$ ). The $\mathrm{CaSO}_{4}$ and $\mathrm{NaSO}_{4}$ ion pairs influence the solubility of calcium- and sulfate-containing minerals, such as gypsum. In addition, because these ion pairs have lower charges than the free ions, their presence complicates the calculation of TDS from EC values and impacts the behavior of ions in the chemical analysis of water samples (Hem, 1992). This ion pair phenomenon and the high solubility of gypsum compared with that of calcite (Appelo and Postma, 1994) account for the lack of sulfatemineral supersaturation for any of 83 water quality analyses for Ponca Creek, although $\mathrm{SO}_{4}$ values approach $1000 \mathrm{mg} / \mathrm{L}$.

The 83 Ponca Creek analyses yielded calculated $\mathrm{pCO}_{2}$ values ranging from 5.12E-04 atm (May 1969) to $2.47 \mathrm{E}-02 \mathrm{~atm}$ (January 1971), with a median of 2.51E-03 atm and an average measured $\mathrm{pH}$ of 7.9. For comparison purposes, $\mathrm{pCO}_{2}$ for the present-day atmosphere is 3.16E-04 atm (Appelo and Postma, 1994). Seventeen Verdigre Creek analyses spanning the period August 1968 through October 1975 were input to Visual MINTEQ, yielding equilibrium $\mathrm{pCO}_{2}$ values ranging from 4.75E-04 atm (October 1972) to 2.69E-02 atm (August 1968) and a median of 1.26E-03 atm. The average measured $\mathrm{pH}$ for these water samples was 7.9 , identical with the mean for the Ponca Creek analyses. The two times higher median $\mathrm{pCO}_{2}$ value for Ponca Creek most likely is in part caused by its significantly higher dissolved solids content. This 2:1 ratio is consistent with the finding that $\mathrm{pCO}_{2}$ increases with increasing concentrations of dissolved calcium carbonate, including $\mathrm{HCO}_{3}$ (Foster, 1950; Plummer et al., 1976; Atkinson, 2011).

Seventy-four Ponca Creek analyses (89\% of sample analyses evaluated) were slightly supersaturated relative to at least calcite; and numerous analyses were slightly supersaturated with respect to aragonite and/or dolomite. Median positive calcite saturation index (SI) is low, 0.69 (positive values denote supersaturation). No analysis was supersaturated relative to gypsum or anhydrite, although six samples contained at least $800 \mathrm{mg} / \mathrm{L}$ of $\mathrm{SO}_{4}$. No minerals were at equilibrium $(\mathrm{SI}=0)$. Thirteen of 17 Verdigre Creek analyses were slightly supersaturated relative to at least calcite; and several of these analyses were slightly supersaturated with respect to aragonite and/or dolomite. Median positive calcite SI is low, 0.60. Like Ponca Creek, no Verdigre Creek sample was supersaturated relative to gypsum or anhydrite.

Visual MINTEQ was used to calculate the concentrations of $\mathrm{Ca}$ and $\mathrm{SO}_{4}$ required to produce theoretical precipitation of gypsum in Ponca Creek water under 
equilibrium conditions. A February 7, 1972, chemical analysis containing a $\mathrm{SO}_{4}$ concentration of $980 \mathrm{mg} / \mathrm{L}$ and a calculated TDS content of $1700 \mathrm{mg} / \mathrm{L}$ was used as a starting point. The $\mathrm{pH}$ was reduced from 7.7 to 7.2 , and concentrations of $\mathrm{Ca}$ and $\mathrm{SO}_{4}$ were gradually increased as those of other major ions were decreased. Applying $\mathrm{HCO}_{3}$ of $73 \mathrm{mg} / \mathrm{L}$ and $1700 \mathrm{mg} / \mathrm{L}$ TDS as equilibrium concentration constraints, gypsum precipitation was not achieved. Increasing Ca a total of $77 \%$ to $580 \mathrm{mg} / \mathrm{L}, \mathrm{SO}_{4}$ a total of $35 \%$ to $1320 \mathrm{mg} / \mathrm{L}$, and TDS to $1960 \mathrm{mg} / \mathrm{L}$ yielded a calculated gypsum SI of 0.003 . These modeling results substantiate the high aqueous solubility of $\mathrm{SO}_{4}$ and the absence of supersaturated conditions in Ponca Creek discharge examined for this study.

Most of the samples exceeded the USEPA secondary (esthetic quality) maximum contaminant level for $\mathrm{SO}_{4}$ in drinking water supplies-250 mg/L (USEPA, 2000). In addition, given the median TDS value of $980 \mathrm{mg} / \mathrm{L}$, many samples exceeded the secondary drinking water standard for TDS of $500 \mathrm{mg} / \mathrm{L}$.

A plausible approximation of the $\mathrm{SO}_{4}$ mass flux for Ponca Creek at the Verdel, Nebraska, gaging station can be calculated using the median $\mathrm{SO}_{4}$ concentration and the median creek discharge for the study period. These values yield a calculated mass discharge of $14,000 \mathrm{~kg} /$ day $(30,900 \mathrm{lb} /$ day $)$. The median mass flux for TDS in Ponca Creek discharge was also calculated, resulting in a daily flux of approximately $30,000 \mathrm{~kg} /$ day $(66,000 \mathrm{lb} /$ day $)$. Although the median discharge of Verdigre Creek near Verdigre $\left(3.17 \mathrm{~m}^{3} / \mathrm{s}\left[112 \mathrm{ft}^{3} / \mathrm{s}\right]\right)$ is an order of magnitude higher than for Ponca Creek, the median mass flux for $\mathrm{SO}_{4}$ is about $7400 \mathrm{~kg} /$ day $(16,300 \mathrm{lb} /$ day $)$, approximately one half of that for Ponca Creek.

\section{CONCLUSIONS}

More than 80 complete water quality analyses for water samples collected from Ponca Creek at Verdel, Nebraska, during about a 12-yr period, reveal notably high sulfate concentrations, ranging from approximately 110 to $1000 \mathrm{mg} / \mathrm{L}$, with a median of $450 \mathrm{mg} / \mathrm{L}$. Nearby streams in eastern Nebraska typically have recorded much lower sulfate concentrations, in the range of approximately 10 to $200 \mathrm{mg} / \mathrm{L}$. Ponca Creek water is a calcium sulfate hydrochemical facies with a median TDS of $980 \mathrm{mg} / \mathrm{L}$, whereas most surrounding surface water, including that occurring in nearby Verdigre Creek, is of the calcium bicarbonate type and contains notably less TDS.

Public domain geochemical equilibrium speciation software was used to investigate aqueous $\mathrm{SO}_{4}$ geochemistry of Ponca Creek flow. Calculated saturation indices for Ponca Creek waters suggest that they are slightly undersaturated with respect to gypsum and anhydrite despite significant sulfate dissolution and are slightly supersaturated with respect to calcite in numerous samples.

Research into probable sources of the elevated $\mathrm{SO}_{4}$ in the mostly ephemeral Ponca Creek revealed that a Late Cretaceous shale, the Pierre Shale, crops out or is near the land surface throughout most of the creek's drainage area in Boyd County. For Verdigre Creek and other nearby streams, alluvium, other Quaternary deposits, or the Tertiary Ogallala Formation comprise the streambed, and the uppermost bedrock is much younger than the Pierre Shale, commonly the Ogallala Formation of Tertiary age. The Ogallala Formation does not contain appreciable quantities of sulfate minerals.

The Pierre Shale, including soils formed on this Cretaceous shale, is rich in sulfate-bearing minerals (e.g., gypsum, pyrite, jarosite) that comprise the principal source of the high sulfate in drainage basin soils, alluvium, creek discharge, and shallow groundwater of the Ponca Creek watershed. Pyrite occurring in the Pierre Shale is exposed to oxidation as overland runoff across moderate to steep valley slopes of Ponca Creek erodes the Pierre Shale, allowing the formation of significant dissolved concentrations of $\mathrm{SO}_{4}$ in runoff water reaching Ponca Creek. In addition, this widespread runoff and erosion contributes to significant dissolution of gypsum, resulting in increased dissolved concentrations of $\mathrm{Ca}$, as well as enriching $\mathrm{SO}_{4}$ concentrations.

Relatively high median concentrations of $\mathrm{SO}_{4}$ and TDS in Ponca Creek discharge diminish its usefulness as a drinking water source. Significantly high calculated median $\mathrm{SO}_{4}$ and TDS mass flux for Ponca Creek at the Verdel, Nebraska, gaging station, $14,000 \mathrm{~kg} /$ day $(31,000 \mathrm{lb} /$ day $)$ and 30,000 kg/day $(66,000 \mathrm{lb} /$ day $)$, respectively, negatively impacts the nonpotable beneficial uses of this ephemeral/perennial stream (e.g., crop irrigation, stock watering, industrial process and makeup water).

The geochemical evaluation and modeling comprising this study substantiate the primary investigation hypothesis that the uppermost and widely exposed bedrock unit, the Pierre Shale, contains abundant sulfur minerals (e.g., pyrite, gypsum, jarosite) that constitute the principal source of significant $\mathrm{SO}_{4}$ concentrations 
in Ponca Creek water. The secondary hypothesisdissolved $\mathrm{SO}_{4}$ concentrations in Ponca Creek during the study period represent equilibrium conditions (i.e., present concentrations approximate 1970-1980 concentrations) - remains untested and should be addressed by collecting at least two quarterly (e.g., spring, fall) water samples at the Verdel sampling station and analyzing them for all major cations and anions, TDS, pH, EC, and water temperature.

\section{REFERENCES CITED}

Allison, J. D., D. S. Brown, and K. J. Novo-Gradac, 1991, MINTEQA2/PRODEFA2, A geochemical assessment model for environmental systems: Version 3.0 User's Manual: Environmental Research Laboratory, Office of Research and Development, U.S. Environmental Protection Agency, Athens, Georgia, 107 p.

Appelo, C. A., and D. Postma, 1994, Geochemistry, groundwater and pollution: Rotterdam, Netherlands, A. A. Balkema, 536 p.

Atkinson, J. C., 2011, Geochemistry analysis and evolution of Bolson Aquifer, Basin and Range province, in southwestern United States: Environmental Earth Sciences Journal, v. 64, no. 1, p. 37-46, doi:10.1007/s12665-010-0814-x.

Bartos T., and K. M. Ogle, 2002, Water quality and environmental isotopic analyses of groundwater samples collected from the Wasatch and Fort Union formations in areas of coalbed methane development: Implications to recharge and groundwater flow, eastern Powder River Basin, Wyoming: U.S. Geological Survey Water Resources Investigation Report 02-4045, Reston, Virginia, $21 \mathrm{p}$.

Bohn, H. L., B. L. McNeal, and G. A. O'Connor, 1979, Soil chemistry: New York, New York, John Wiley \& Sons, Inc, 365 p.

Byrd, W. J., and S. S. Kaplan, 1994, Report on the geology and hydrology of the area between proposed LLRW site and Dizzy Creek and associated areas: University of Nebraska-Lincoln, Department of Geology, Lincoln, Nebraska, UNL Document 3250, $26 \mathrm{p}$.

Davis, A. D., and A. J. Long, 1998, Numerical simulation of groundwater flow at the proposed low-level radioactive waste disposal facility in Boyd County, Nebraska: Prepared for Boyd County Low-Level Waste Monitoring Committee, Butte, Nebraska, 17 p.

Degens, E. T., 1965, Geochemistry of sediments: A brief survey: Englewood Cliffs, New Jersey, Prentice-Hall, 219 p.

Diffendal, R. F., 2004, Papers in natural resources: Ogallala Aquifer: School of Natural Resources, University of Nebraska-Lincoln, Lincoln, Nebraska, 6 p.

Engberg, R. A., 1984, Appraisal of data for groundwater quality in Nebraska: U.S. Geological Survey Water-Supply Paper 2245, 54 p.

Foster, M. D., 1950, The origin of high sodium bicarbonate waters in the Atlantic and Gulf coastal plains: Geochimica et Cosmochimica Acta, v. 1, p. 33-38.

Gustafsson, J. P., 2009, Visual MINTEQ, Version 2.62: KTH School of Architecture and Built Environment, Department of Land and Water Resources Engineering, Stockholm, Sweden.

Hem, J. D., 1992, Study and interpretation of the chemical characteristics of natural water: U.S. Geological Survey Water Supply Paper 2254, Reston, Virginia, 264 p.

Indra, O., 1979, Soil survey of Boyd County, Nebraska: U.S. Department of Agriculture Soil Conservation Service, in cooperation with University of Nebraska Conservation and Survey Division, Lincoln, Nebraska, 173 p.
NRCS (Natural Resources Conservation Service), 2011a, Web Soil Survey: http://websoilsurvey.nrcs.usda.gov/app/HomePage .htm (accessed June 2, 2011).

NRCS (Natural Resources Conservation Service), 2011b, Soil Survey Laboratory Information Manual: U.S. Department of Agriculture, Soil Survey Investigations Report 45, v. 2.0, 165 p.

NRCS (Natural Resources Conservation Service), 2011c, National Soil Science Laboratory (National Cooperative Soil Survey), National Cooperative Soil Characterization Database: http://ssldata .nrcs.usda.gov (accessed June 5, 2011).

Pierzynski, G. M., J. T. Sims, and G. F. Vance, 2000, Soils and environmental quality, 2d ed.: Boca Raton, Florida, Lewis Publishers, $410 \mathrm{p}$.

Piper, A. M., 1944, A graphic procedure in the geochemical interpretation of water analyses: American Geophysical Union Transactions, v. 25, p. 914-923.

Plummer, L. N., H. L. Vacher, F. T. Mackenzie, O. P. Bricker, and L. S. Land, 1976, Hydrogeochemistry of Bermuda: A case history of groundwater diagenesis of biocalcarenites: Geological Society of America Bulletin, v. 87, p. 1301-1316, doi:10.1130/0016 -7606(1976)87<1301:HOBACH>2.0.CO;2.

Rahn, P. H., and A. D. Davis, 1989, Hydrogeology of the proposed low-level radioactive waste site in Boyd County, Nebraska: Report prepared for Boyd County Low-Level Waste Monitoring Committee, Butte, Nebraska, 24 p.

Schultz, L. G., H. A. Tourtelot, J. R. Gill, and J. G. Boerngen, 1980, Composition and properties of the Pierre Shale and equivalent rocks, northern great plains region: Geochemistry of the Pierre Shale and equivalent rocks of Late Cretaceous age: U.S. Geological Survey Professional Paper 1064-B, 38 p.

Souders, V. L., 1976, Physiography, geology, and water resources of Boyd County, Nebraska: Conservation and Survey Division, Institute of Agriculture and Natural Resources, University of Nebraska-Lincoln, Lincoln, Nebraska, Nebraska Water Survey Paper 42, 113 p.

Spalding, R. F., and M. E. Exner, 1980, Areal, vertical, and temporal differences in groundwater chemistry: I. Inorganic constituents: Journal Environmental Quality, v. 9, no. 3, p. 466-479, doi:10.2134/jeq1980.00472425000900030030x.

Sposito, G., 1989, The chemistry of soils: New York, New York, Oxford University Press, 395 p.

Stiff Jr., H. A., 1951, The interpretation of chemical water analysis by means of pattern: Journal Petroleum Technology, v. 3, no. 10, p. $15-17$

Tabatabai, M. A., 1982, Sulfur, in A. L. Page, R. H. Miller, and D. R. Keeney, eds., Methods of soil analysis, Part 2, Chemical and microbiological properties, 2 d ed.: Agronomy, v. 9, p. 501538.

Tabatabai, M. A., 1996, Sulfur, in D. L. Sparks, ed., Methods of soil analysis, Part 3, Chemical methods: Soil Science Society America Book Series 5, ASA and SSSA, Madison, Wisconsin, 42 p.

U.S. Ecology, 1990, Safety analysis report: Central Interstate Compact Low-Level Radioactive Waste Disposal Facility license application, $22 \mathrm{p}$.

USEPA (U.S. Environmental Protection Agency), 2000, Drinking water standards and health advisories: Washington, D.C., Office of Water, $16 \mathrm{p}$.

USEPA (U.S. Environmental Protection Agency), 2011, STORET Web site: http://www.epa.gov/storet/ (accessed June 20, 2011).

U.S. Geological Survey, 2011, Water quality Web site: http://waterdata.usgs.gov/ne/nwis/qw (accessed June 30, 2011).

Zipper, C., J. Skousen, and C. R. Jage, 2011, Reclamation guidelines for surfaced mined lands: Passive treatment of acid-mine drainage: Virginia Cooperative Extension Publication 460-133: http ://pubs.ext.vt.edu/460/460-133/460-133.html (accessed July 10, 2011). 